\title{
CLONING A LYSINE-RICH PROTEIN GENE FROM POTATO \\ (Solanum tuberosum L.) CULTIVAR THUONG TIN AND CONSTRUCTION OF THE EXPRESSION VECTOR
}

\author{
Tran Thi Luong, Nguyen Thuy Ninh, Nguyen Duc Thanh* \\ Institutre of Biotechnology, VAST
}

\begin{abstract}
Lysine is one of the limiting essential amino acids because it is not synthesized in the body of animals and human. They must obtain lysine from their diet. Recent results of gene transfer research showed the possibility of overexpression of genes encoding natural lysine-rich proteins in crops such as rice and corn, to improve protein quality by increasing the lysine content. However, there has been little report on cloning genes for lysine-rich proteins. In this article, we present the results of cloning the STtLR gene encoding a lysine-rich protein from Thuong Tin potato cultivar. After successful cloning, we have constructed an expression vector to be used for gene transfer. The cloned gene had similarities of $94 \%$ and $99 \%$ to the $S B g L R$ sequences that were registered in GenBank with the accession numbers KU987257.1 and AY377987.1, respectively. The deduced amino acid sequence of STtLR protein has high lysine proportion of $16.9 \%$. In addition, glutamic acid component was also high with the value of $22.8 \%$. Thus, the cloned gene is considered as the gene encoding a lysine - and glutamic acid-rich protein. STtLR gene was successfully cloned into the plant expression vector pCAMBIA2300 under the control of globulin 1 promoter (Glo1) from maize. These results provide a useful tool for genetic engineering to improve the quality of protein in crop plants.

Keywords: Thuong Tin potato, lysine-rich protein, STtLR gene, expression vector.
\end{abstract}

Citation: Tran Thi Luong, Nguyen Thuy Ninh, Nguyen Duc Thanh, 2016. Cloning a lysine-rich protein gene from potato (Solanum tuberosum L.) cultivar Thuong Tin and construction of the expression vector. Tap chi Sinh hoc, 38(4): 497-504. DOI: 10.15625/0866-7160/v38n4.8973.

*Corresponding author: nguyenducthanh_pcg@ibt.ac.vn

Received 7 December 2016, accepted 20 December 2016

\section{INTRODUCTION}

Proteins of cereals and some legume crops have relatively low nutrition values due to low content of essential amino acids, particularly, lysine, tryptophan and methionine. Therefore, enhancement of essential amino acids contents in crop plants is an important target of plant biotechnology. Lysine is the most important amino acid among the 12 essential amino acids that human body needs in the daily diet. It enhances calcium absorption and maintains calcium level, and prevents the excretion of minerals from the body. Thus, lysine affects the height growth and prevents osteoporosis. Since humans and animals cannot synthesize lysine, it should be supplied from the daily diet. Chronic nutrient-deficient diet leads to poor growth, illness and in severe cases, leads to death. Lysine is the most limiting amino acid in cereals. For the enrichment of protein quality of cereals and other crops, improvement of lysine content is essential (Ferreira et al., 2005; Sofi et al., 2009). One of the strategies to increase the essential amino acids, in particular, lysine, is to increase the protein sink by transforming plants with genes encoding stable proteins that are rich in the desired amino acid (Ufaz, Galili, 2008). This can be done by exploiting the recombinant genes encoding lysine-rich proteins such as natural genes encoding lysine-rich proteins derived from plants (Sun et al., 2001; Yu et al., 2004; Wong et al., 2015; Liu et al., 2016) or other sources (Shaul, Galili, 1992), mutated natural genes that can increase the number of lysine codons and make lysine-rich proteins (Roesler, Rao, 2000), and synthetic genes encoding lysine-rich proteins (Jiang et al. 2016). 
A natural lysine-rich protein gene $S B g L R$ was isolated and cloned from the genomic DNA library of potato using cDNA SB401 as the probe (Lang et al., 2004). The $S B g L R$ gene has three exons and two introns encoding a natural lysine-rich 211 amino acid protein with lysine proportion of $18.93 \%$. Initial findings show that the transfer of $S B g L R$ and $S B 401$ under the control of the specific promoter $\mathrm{P} 19 \mathrm{z}$ for protein expression in maize kernels increased the lysine content from $16.1 \%$ to $54.8 \%$ (Lang et al., 2005; Yu et al., 2004) compared with nontransgenic control. Recently, a natural lysinerich protein gene GhLRP from cotton was isolated and after transfer of this gene to maize under the control of F128, the seed-specific promoter for gene expression in seeds, lysine content of the transgenic maize increased from 16.2 to $65 \%$ (Yue et al., 2014) .

In this paper, we present the results of cloning the STtLR gene encoding lysine-rich proteins from Thuong Tin potato cultivar and constructing the expression vector. The results of this study will provide a useful tool for genetic engineering to improve the quality of protein in crop plants.

\section{MATERIALS AND METHODS}

Potato (Solanum tuberosum L.) cultivar Thuong Tin was provided by the Institute of Agricultural Biology, Vietnam National University of Agriculture, Hanoi, Vietnam. Cloning vector pJET1.2/blunt, Dream Taq DNA polymerase, dNTPs, Reverse Transcriptase Kit RevertAidH Minus, GeneJET Gel Extraction Kit, GeneJET PCR Purification Kit, and restriction enzymes were purchased from Thermo Fisher Scientific (Massachusetts, USA). Chemicals used to extract DNA and RNA were supplied by Sigma-Aldrich (Missouri, USA). E. coli strain DH5 $\alpha$ and Agrobacterium tumefaciens strain EHA105 were provided by Plant Cell Genetics Laboratory, Institute of Biotechnology (Hanoi, Vietnam).

Specific primers for amplification of STtLR gene: StLR-F 5'- GGATCCATGGGTT GTGGGGAATCAAAGC-3' with BamHI recognition site and StLR-R: 5'-GCGAGCTCT CAATCTGTTTTTGAATCTGTTGCTG-3'

with $S a c$ I recognition site and specific primers for Globulin 1 (Glo1) promoter: Glo1-F: 5'AAGC TTGCACGGTAAGGAGAGTACGG3' with HindIII recognition site and Glo1-R: 5'GGATCCGTGATGAC CAGTTTCTTCCG-3' with BamHI recognition site were designed using the Primer 3 (NCBI) based on the gene sequence information of $S B g L R$ (AY377987. 1) and Globulin 1 (EU643507.1).

\section{cDNA synthesis and STtLR gene amplification}

Total RNA was extracted from the leaf samples of in vitro cultured potato plants using Trizol reagent according to the manufacturer's instructions (Invitrogen, USA). cDNA synthesis from the extracted RNA was performed using Reverse Transcriptase kit RevertAidH Minus (Thermo Scientific). STtLR gene was amplified using the specific primers on Q-Cycler II (Quanta Biotech, England) with the following program: $94^{\circ} \mathrm{C}$ for $5 \mathrm{~min}$; 35 cycles consisting of $94^{\circ} \mathrm{C}$ for $1 \mathrm{~min} ; 60^{\circ} \mathrm{C}$ for $50 \mathrm{sec}, 72^{\circ} \mathrm{C}$ for 1 min $30 \mathrm{sec}$; ending cycle of $8 \mathrm{~min}$ at $72^{\circ} \mathrm{C}$. The PCR reaction mixture includes $1 \mu \mathrm{lDNA} ; 12.5$ $\mu \mathrm{l}$ of 10x PCR buffer; $1.5 \mathrm{mM}$ of $\mathrm{MgCl} 2 ; 200$ $\mu \mathrm{M}$ of each dNTP; $50 \mathrm{ng}$ of forward primer, 50 ng of reverse primer; $1 \mu \mathrm{l}$ of Taq DNA polymerase $(5 \mathrm{U} / \mathrm{l})$ and $12 \mu \mathrm{l}$ of sterilized distilled water. PCR products were electrophoresed on $1 \%$ agarose gel. Purified PCR products were ligated to the cloning vector pJET1.2 and transformed into $E$. coli strain $\mathrm{DH} 5 \alpha$ by heat shock at $42^{\circ} \mathrm{C}$ for $60 \mathrm{sec}$. Bacteria carrying the recombinant vector were grown on the selective medium containing ampicillin. The bacterial strains grown on the selective media were checked for the presence of the transformant by colony-PCR method using specific primers and by cleaving recombinant plasmid with appropriate restriction enzymes.

The molecular biology techniques for recombinant DNA manipulation such as plasmid DNA extraction, cloning DNA fragments into expression vectors, and restriction enzyme cleavage of DNA sequences, 
were conducted as described by Sambrook and Russell (2001). Recombinant plasmids were selected, purified and sequenced on ABI automated Avant Genetic Analyzer PRISM 3100 (Applied Biosystems, Massachusetts, USA).The cloned gene is denoted as STtLR (Lysine-Rich protein gene from Solanum tuberosum cultivar Thuong tin).

\section{Gene and protein analyses}

Nucleotide sequence alignment and open reading frame finding were performed using the BLAST and ORF Finder Programs at NCBI website. We used SmartBLAST (NCBI website) for multiple alignments of protein sequences. Analysis of amino acid composition of the deduced protein was carried out using ProtParam Program (Gasteiger et al., 2005).

\section{Construction of Expression vector}

STtLR gene was cloned into an expression vector pCAMBIA2300 with Globulin 1 (Glo1) promoter that was isolated from CML161 maize line (KX401329) using T4 ligase enzyme and was conducted by the method described by Sambrook and Russell (2001). Expression vector pCAMBIA/Glo1/STtLR/Nos was then transformed into Agrobacterium tumefaciens strain EHA105 using an electroporation method. The competent cells of $A$. tumefaciens and transformation process were conducted according to the method described by McCormac et al. (1998).

\section{RESULTS AND DISCUSSIONS}

\section{Cloning of STtLR gene}

The full length of the target cDNA was synthesized from total RNA extracted from the leaves of Thuong Tin potato cultivar (fig. 1). Figure 1 shows two isolated RNA samples with typical fragments of $18 \mathrm{~S}$ and $28 \mathrm{~S}$ RNA. Figure 2 shows the results of RT-PCR amplification of STtLR gene from cDNA using the specific primers StLR-F and StLR-R. From two cDNA samples, we obtained a clean band of each, with no smears, of approximately $660 \mathrm{bp}$, corresponding to the expected length of the STtLR gene (fig. 2, lane 1 and 2). Thus, presumably we have successfully amplified the
STtLR gene.

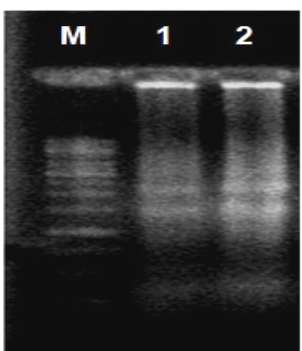

Figure 1. Total RNA from potato Thuong Tin was electrophoresed on $1 \%$ agarose gel. 1-2: total RNA; M: Ladder $1 \mathrm{~kb}$

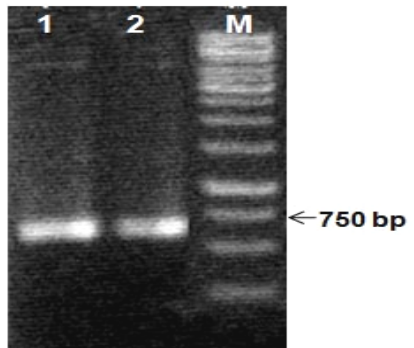

Figure 2. Amplified STtLR gene from cDNA of Thuong Tin potato cultivar. 1-2: STtLR gene; $\mathrm{M}$ : Ladder $1 \mathrm{~kb}$

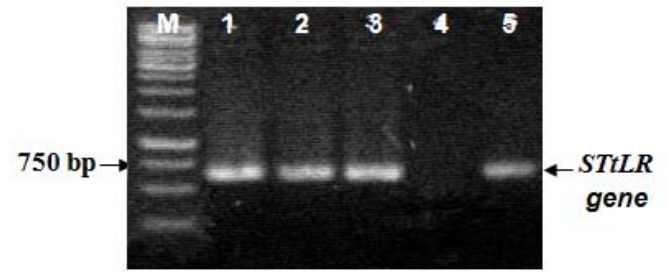

Figure 3. Colony PCR showing the presence of STtLR gene in 4 recombinant colonies. 1-5: recombinant colonies, $\mathrm{M}$. Ladder $1.0 \mathrm{~kb}$

\section{Sequencing and analysis of $S T t L R$ gene}

Purified fragment of STtLR gene was subcloned into the cloning vector pJET1.2/blunt using T4 ligase enzyme to create the plasmid pJET1.2/STtLR. After transformation into competent E. coli DH5 $\alpha$ cells, the cells were cultured on LB medium supplemented with ampicillin $(50 \mathrm{mg} / \mathrm{l})$ and incubated at $37^{\circ} \mathrm{C}$ for $16 \mathrm{hr}$. Five colonies were selected to perform colony-PCR with specific primers StLR-F and StLR-R to determine the presence of inserted STtLR gene in the pJET1.2/STtLR plasmid. Results of colony-PCR showed one of five 
colonies gave a negative result (lane 4, fig. 3), while four colonies have a unique fragment of about $660 \mathrm{bp}$ in size (lanes 1, 2, 3 and 5, fig. 3) which corresponds to the size of the STtLR gene.

Furthermore, to confirm the clone, we performed insert release with specific restriction enzymes. Plasmid DNA was isolated from colonies carrying the recombinant plasmid pJET1.2/STtLR and digested with the restriction enzymes, BamHI and SacI. We obtained two fragments of $3000 \mathrm{bp}$ and $660 \mathrm{bp}$, the former corresponds to the vector pJET1.2 while the latter corresponds to the size of the STtLR gene (fig. 4).

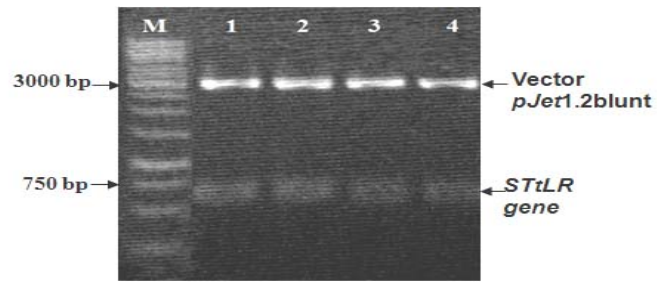

Figure 4. Restriction enzyme cleavage of recombinant plasmid using BamHI and SacI.14: Plasmid DNA from recombinant colonies. M: Ladder $1.0 \mathrm{~kb}$.

Purified recombinant plasmid DNA was sequenced using an Automatic Avant Genetic Analyzer ABI PRISM $3100 \quad$ (Applied Biosystems) at the Key Laboratory of Gene
Technology, Institute of Biotechnology, Vietnam. The forward (pJet1.2F) and reverse (pJet1.2R) primers for vector pJET1.2/blunt were used for sequencing. The obtained STtLR gene sequence was 659 bp in length, which included the complete gene sequence with ORF starting at $1^{\text {st }}$ nucleotide and ending at $657^{\text {th }}$ nucleotide. Thus, we confirmed that our clone has the correct STtLR gene.

\section{STtLR gene and protein sequences analyses}

STtLR gene had similarity of $94 \%$ and $99 \%$ with the genes encoding lysine-rich proteins of potatos that were registered in GenBank with the Accession numbers AY377987.1 and KU987257.1, respectively. The deduced protein was composed of 219 amino acids. The results of SmartBlast search revealed high similarity between STtLR protein and a lysine-rich protein from Solanum tuberosum (Accession No. AMX23138.1) with 100\% similarity and with another glutamic acid-rich protein from Solanum berthaultii (Accession No.CAA65228.1) at $82 \%$ similarity. STtLR protein was grouped with three best matches in the sequence database, glutamic acid-rich protein from Solanum berthaultii, TSB from Solanum lycopersicum, and lysine-rich protein from Solanum tuberosum, together with the two best matches from well-studied reference species, isoform $\mathrm{X} 2$ and $\mathrm{X} 3$ of methyltransferase of Glycine max, based on multiple sequence alignment and conserved protein domains (fig. 5).

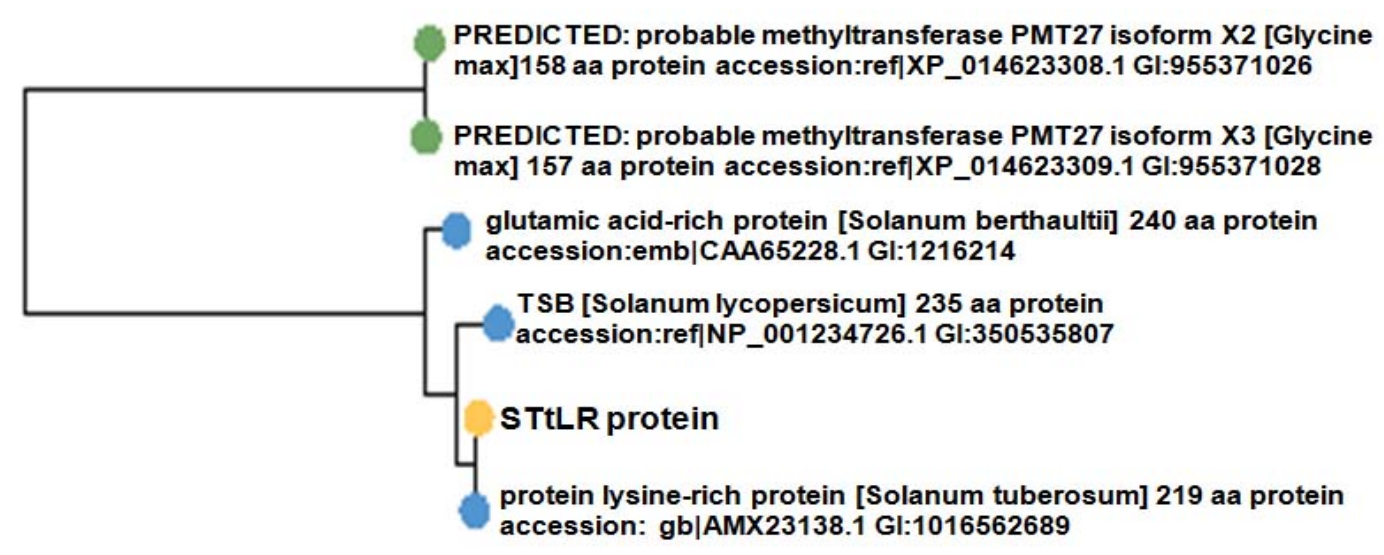

Figure 5. Relationships between STtLR protein and best matches

in the sequence database, together with the two best matches from well-studied reference species 


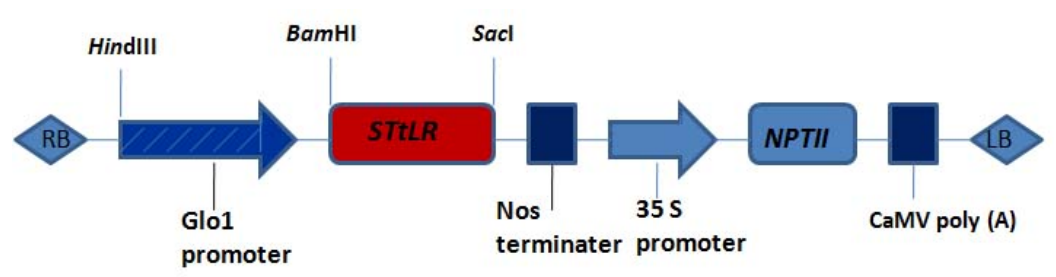

Figure 6. Schematic construct of pCAMBIA2300/Glo1/STtLR/Nos vector

Table 1. Amino acid proportions in STtLR protein as calculated by ProtParam Program

\begin{tabular}{llcc}
\hline \multicolumn{1}{c}{ Amino acid } & Abbr. & Numbers & $\begin{array}{c}\text { Prop. } \\
(\%)\end{array}$ \\
\hline Alanine & Ala & 18 & 8.2 \\
Arginine & Arg & 1 & 0.5 \\
Asparagine & Asn & 10 & 4.6 \\
Aspartac acid & Asp & 9 & 4.1 \\
Cysteine & Cys & 1 & 0.5 \\
Glutamic & Glu & $\mathbf{5 1}$ & $\mathbf{2 3 . 3}$ \\
acid & & & \\
Glutamine & Gln & 1 & 0.5 \\
Glycine & Gly & 5 & 2.3 \\
Histidine & His & 2 & 0.9 \\
Isolecine & Ile & 7 & 3.2 \\
leusine & Leu & 3 & 1.4 \\
Lysine & Lys & $\mathbf{3 7}$ & $\mathbf{1 6 . 9}$ \\
Methionine & Met & 2 & 0.9 \\
Phenylalanine & Phe & 0 & 0 \\
Proline & Pro & 10 & 4.6 \\
Serine & Ser & 14 & 6.4 \\
Threonine & Thr & 20 & 9.1 \\
Triptophan & Trp & 0 & 0 \\
Tyrasine & Tyr & 0 & 0 \\
Valine & Val & $\mathbf{2 8}$ & $\mathbf{1 2 . 8}$ \\
\hline
\end{tabular}

The results of amino acid composition analysis of STtLR proteins by ProtParam Program (Gasteiger et al., 2005) showed high proportion of lysine component (16.9\%) comparable to those of $S B g L R$ gene with Accession No. AY377987.1 (16.58). In addition, glutamic acid (23.3\%) and a number of other essential amino acids such as valine $(12.8 \%)$ and threonine $(9.1 \%)$ were rather high (table 1). The results obtained indicate our successful isolation and cloning of the STtLR gene encoding a lysine-rich protein from Thuong Tin potato cultivar. The cloned STtLR gene was registered to GenBank with the Accession number KX792095.1.

\section{Construction of the expression vector}

STtLR gene was cloned into plant expression vector pCAMBIA2300 with the seed specific promoter Glol to create pCAMBIA2300/Glo1/STtLR/Nos vector carrying STtLR gene (fig. 6).

The expression structure pCAMBIA2300/ Glo1/STtLR/Nos was then transformed into $E$. coli DH5 $\alpha$. Results of colony PCR of recombinant plasmid using the forward primer for Glo1 promoter (Glo1-F: 5'AAGCTTGCAC GGTAAGGAGAGTACGG) and reverse primer for STtLR gene (StLR-R: 5'-GCGAGCTCTCA ATCTGTTTTTGAATCTGTTGCTG-3').

Figure 7 showed a fragment of $1600 \mathrm{bp}$ corresponding to the required size of $930 \mathrm{bp}$ of Glo1 promoter plus $659 \mathrm{bp}$ of STtLR gene. The results show that the expression structure pCAMBIA2300/Glo1/STtLR/Nos has been successfully transferred into $E$. coli $\mathrm{DH} 5 \alpha$.

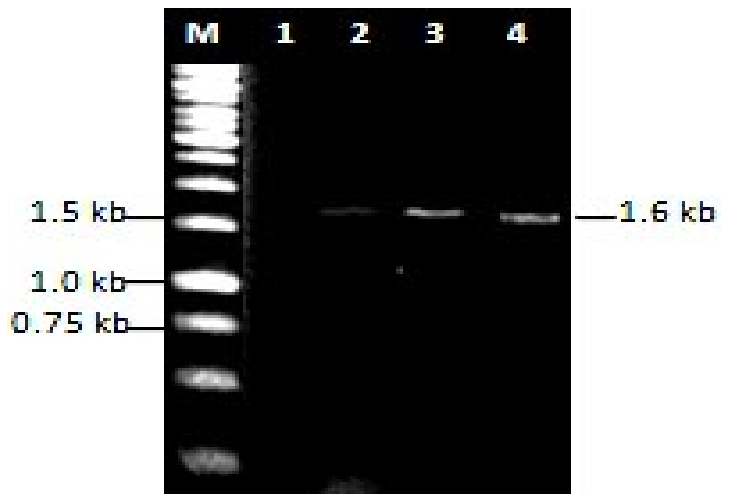

Figure 7. Colony PCR showing 2 recombinant E. coli colonies carrying Glo1 promoter and STtLR gene. 1-4: E. coli colonies. M: Ladder $1.0 \mathrm{~kb}$ 
We have obtained similar results when transferring the expression structure pCAMBIA2300/Glo1/STtLR/Nos into Agrobacterium tumefaciens strain EHA105 using electroporation and verifying the presence of target genes by colony PCR using Glo1-F 5'AAGCTTGCACGGTAAGGAGAGTACGG) and StLR-R 5'-GCGAGCTCTCAATCTGTTT TTGAATCTGTTGCTG-3' primers (data not shown).

\section{DISCUSSION AND CONCLUSIONS}

Currently, the use of genes from plants to produce genetically modified (GM) crops (cistrangenic) has profoundly attracted scientists to develop environmentally friendly GM crops. One of the strategies to improve protein quality is to produce transgenic plants by overexpressing genes encoding the proteins with higher ratios of essential amino acids, particularly, lysine. Several lysine-rich protein genes such as $S B 401$ [18] and $S B g L R$ [Lang et al., 2004; Wang et al., 2013; Yu et al., 2004] from potato, GhLRP [Tang et al, 2013; Yue et al., 2014] from cotton and LRP [Sun et al., 2001] from winged bean have been reported. However, the number of such lysine-rich genes is still limited. In this study, we have successfully cloned and characterized the STtLR gene from potato cultivar Thuong Tin. The cloned gene had high similarity to the $S B g L R$ sequences. The deduced protein of the STtLR gene had high proportion of lysine $(16.9 \%)$ and glutamic acid $(23.3 \%)$. In addition, the ratios of other essential amino acids such as valine $(12.8 \%)$ and threonine $(9.1 \%)$ were also high. The deduced amino acid sequence of STtLR protein was completely identical with that of lysine-rich protein (AMX23138.1) of Solanum tuberosum, and have $82 \%$ similarity with the glutamic acid-rich protein (CAA65228.1) from Solanum berthaultii. These results indicate that the cloned gene STtLR belongs to a lysine-rich protein gene and will be useful for gene transfer research towards the improvement of protein quality of important crops like maize, rice and soybean.

So far, lysine-rich protein genes have been attempted to transfer into cereal crops like maize under the control of seed-specific promoters $\mathrm{P} 19 \mathrm{z}$ (Yu et al., 2004; Yue et al., 2014) and F128 (Yue et al., 2014), and in rice with promoter GT1 (Gluterin 1) (Liu et al., 2016).In this study, we have designed the expression vector pCAMBIA2300/Glo1/STtLR/Nos in which the lysine-rich protein gene STtLR was cloned along with the well-studied Glo1 promoter from maize. This will aid further study on improvement of maize proteins as they consist of mainly (60\%) maize prolamins (zeins) which lack the most limiting essential amino acids, lysine and tryptophan. The Globulin 1 gene encoding globulin that is an abundant protein in embryos of maize and rice and its promoter has been proven to be a seed-specific promoter (Hood et al., 2003). In addition, maize Globulin 1 promoter was also reported to drive gene expression in all tissues of developing maize seeds (Mei et al., 2004)]. Therefore, our expression vector pCAMBIA2300/Glo1/STtLR/ Nos will be useful for the study of the expression of lysine-rich protein gene STtLR in maize in particular, and other cereal crops, in general.

Acknowledgements: This work was supported by Institutional Project CS15-01 from Institute of Biotechnology, Vietnam Academy of Science and Technology. The authors thank Chitra C Iyer from the Ohio State University, Columbus, Ohio, USA for her English editing.

\section{REFERENCES}

Ferreira R. R., Varisi V. A., Meinhardt L. W., Lea P. J., Azevedo R. A., 2005. Are highlysine cereal crops still a challenge. Braz. J. Med. Biol. Res., 38: 985-994.

Gasteiger E., Hoogland C., Gattiker A., Duvaud S., Wilkins M.R., Appel R.D., Bairoch A., 2005.Protein Identification and Analysis Tools on the ExPASyServer; (In) John M. Walker (ed): The Proteomics Protocols Handbook, Humana Press. pp. 571-607.

Jiang S.Y., Ma A., Xie L., Ramachandran S., 2016. Improving protein content and quality by over-expressing artificially synthetic fusion proteins with high lysine and 
threonine constituent in rice plants. Sci. Rep., 6, 34427; doi: 10.1038/srep34427.

Hood E. E., Bailey M. R., Beifuss K., Magallanes-Lundback M., Horn M.E., Callaway E., Drees C., Delaney D. E., Clough R., Howard J. A., 2003. Criteria for high-level expression of a fungal laccase gene in transgenic maize. Plant Biotechnol. J., 1:129-140.

Lang Z., Zhao Q., Yu .J, Zhu D., Ao G., 2004. Cloning of potato $S B g L R$ gene and its intron splicing in transgenic maize. Plant Sci., 166: 1227-1233.

Liu X., Zhang C., Wang X., Liu Q., Yuan D., Pan G., Sun S. S. M., Tul J., 2016. Development of high-lysine rice via endosperm-specific expression of a foreign lysine rich protein gene. BMC Plant Biol., 16:147 DOI 10.1186/s12870-016-0837-x.

Mei C., Wasson J. J., Widholm J. M., 2004. Expression specificity of the Globulin 1 promoter driven transgene (Chitinase) in maize seed tissue. Maydica, 49: 255-265.

McCormac A. C., Elliott M. C., Chen D. F., 1998. A simple method for the production of highly competent cells of Agrobacterium for transformation via electroporation. Mol. Biotechnol., 9 (2): 155-159. doi:10.1007/BF02760816

Roesler K. R., Rao A. G., 2000. A single disulfide bond restores thermodynamic and proteolytic stability to an extensively mutated protein. Protein Sci., 9: 1642-1650

Sambrook J., Russell D. W., 2001. Molecular cloning: A Laboratory Manual, $3^{\text {rd }}$. ed. Cold spring harbor laboratory press, Cold spring harbor, NY.

Shaul O., Galili G., 1992. Increased lysine synthesis in transgenic tobacco plants expressing a bacterial dihydrodipicolinate synthase in their chloroplasts. Plant J.,
2: 203-209.

Sofi P. A., Wani S. A., Rather A. G. S. H., 2009. Review article: Quality protein maize (QPM): Genetic manipulation for the nutritional fortification of maize. J. Plant Breed. Crop. Sc., 1(6): 244-253.

Sun S. S. M., Xiong L. W., Jing Y. X., Liu B. L., 2001. lysine rich protein from winged bean. US Patent. 6,184,437. 2001

Tang M., He X., Luo Y., Ma L., Tang X., Huang K., 2013. Nutritional assessment of transgenic lysine-rich maize compared with conventional quality protein maize. J. Sci. Food Agric., 93: 1049-1054.

Ufaz S., Galili G., 2008. Improving the content of essential amino acids in crop plants: goals and opportunities. Plant Physiol., 147: 954-961.

Wang M., Liu C., Li S., Zhu D., Zhao Q., Zhu J., 2013. Improved nutritive quality and salt resistance in transgenic maize by simultaneously over expression of a natural lysine-rich protein gene, $S B g L R$, and an ERF transcription factor gene, TSRF1. Int. J. Mol. Sci., 14(5): 9459-74.

Wong, H. W., Liu, Q., Sun, S. S., 2015. Biofortification of rice with lysine using endogenous histones. Plant Mol. Biol. $87: 235-248$.

Yu J., Peng P., Zhang X., Zhao Q., Zhu D., Sun X., Liu J., Ao G., 2004. Seed-specific expression of the lysine-rich protein gene sb401 significantly increases both lysine and total protein content in maize seeds. Mol. Breed., 14: 1-7.

Yue J., Li C., Zhao Q., Zhu D., Yu J., 2014. Seed-Specific Expression of a Lysine-rich protein gene, GhLRP from cotton significantly increases the lysine content in maize seeds. Int. J. Mol. Sci.,15: 53505365 . 


\title{
NHÂN DÒNG GEN MÃ HÓA PROTEIN GIẦU LYSINE TÙ GIỐNG KHOAI TÂY THƯỜNG TÍN VÀ THIẾT KẾ VECTOR BIỂU HIỆN
}

\author{
Trần Thị Lương, Nguyễn Thùy Ninh, Nguyễn Đức Thành* \\ Viện Công nghệ sinh học, Viện Hàn lâm KH \& CN Việt Nam
}

\section{TÓM TẮT}

Lysine là một trong các acid amin thiết yếu, nó không được tổng hợp trong cơ thể động vật và người, vì vậy, người và động vật phải được cung cấp lysine thông qua chế độ ăn uống. Kết quả nghiên cứu chuyển gen gần đây đã cho thấy khả năng thể hiện của gen mã hóa protein giàu lysine tự nhiên ở các cây trồng như lúa, ngô trong việc cải thiện chất lượng protein bằng việc gia tăng hàm lượng lysine. Tuy nhiên, cho đến nay có rất ít báo cáo về nhân bản gen mã hóa cho protein giàu lysine. Trong bài này, chúng tôi trình bày các kết quả nhân bản gen $S T t L R$ mã hóa protein giầu lysine từ giống khoai tây Thường Tín và thiết kế vector biểu hiện để sử dụng cho chuyển gen. Gen được nhân dòng có mức tương đồng là $94 \%$ và $99 \%$ so với các trình tự gen SBgLR (mã hóa cho protein giàu lysine) tương ứng được đăng ký trên GenBank với mã số KU987257.1 và AY377987.1. Phân tích các thành phần acid amin của protein STtLR suy diễn, chúng tôi nhận thấy tỷ lệ lysine khá cao và chiếm $16,9 \%$. Ngoài ra, thành phần acid glutamic cũng cao với giá trị là $22,8 \%$; gen nhân dòng có thể được coi như một gen mã hóa protein giàu lysine và acid glutamic. Gen STtLR đã được gắn thành công vào vector biểu hiện pCAMBIA2300 dưới sự điều khiển của promoter globulin 1 (Glo1) từ ngô. Các kết quả của nghiên cứu này là cơ sở cho việc áp dụng các kỹ thuật di truyền trong việc nâng cao chất lượng protein của cây trồng.

Tì khóa: Khoai tây, protein giàu lysine, STtLR gene, vector biểu hiện. 